Henryk Gurgul*, Łukasz Lach*

\title{
Key sectors after a decade of transition: Evidence from Poland
}

\section{Introduction}

More than twenty five years ago, Poland, which is often called a model transition economy ${ }^{1}$, was the first Central and Eastern European (CEE) country that replaced an authoritarian communist regime by a government elected in partlydemocratic election. At the beginning of the transition, Poland and other CEE economies were confronted with many difficult economic and social problems. The process of transition from a centrally-planned economy to a market economy was the very first process of this type in the economic history of the world (and the history of economic thought). There was no theoretical background for such a transition. The state-owned companies lost cooperation and trade links with other former communist Comecon countries and were exhibited to competition by companies from highly-developed Western economies. Thus, it is not surprising that the industrial output, real wages, and salaries were dropping, and at the same time, both inflation and unemployment were rapidly rising ${ }^{2}$. In order to face these rising socio-economic problems, the authorities in Poland decided to apply the so-called shock therapy, which in this context is understood as a rapid adjustment of existing economic rules according to market principles and requirements

* AGH University of Science and Technology, Faculty of Management, Department of Applications of Mathematics in Economics, e-mails: henryk.gurgul@gmail.com (Henryk Gurgul), llach@zarz. agh.edu.pl (Łukasz Lach). We would like to thank anonymous referees for their helpful suggestions on earlier versions of this paper.

1 This opinion is often expressed by both researchers (e.g., Lenain, 2000) and politicians (recall US President Barack Obama hailing Poland as a model of transition during his visits to Warsaw in 2011 and 2014 - for details see: http://www.huffingtonpost.com/2011/05/28/obama-poland-democracy_n_868434.html and http://www.whitehouse.gov/the-press-office/2014/06/04/remarks-presidentobama-25th-anniversary-freedom-day-warsaw-poland).

2 At the early stage of the transition, one could even notice a hyperinflation in Poland as the annual inflation rate reached a level of a few hundred percentage points. 
(i.e., liberalization). In general, this procedure, also known as the Balcerowicz's plan $^{3}$, was aimed at keeping the inflation under control. The first positive effects of the undertaken measures could be observed in trade, and also later in services. However, in the sectors of manufacturing, mining, metallurgy, foundry, and other branches of heavy industry, the economic transformation was generally less successful. Heavy industries were essentially reduced and lost their significance. In other words, the transition process resulted in significant restructuring of the economy under study. One can take for granted that, because of the forthcoming transition process, the importance and size of all sectors change radically. This means that the ranking of importance of the sectors thoroughly changes as well.

The main aim of this contribution is a derivation of the ranking of importance of industries of the Polish economy based on available IO data from the second decade of transition. Since the IO tables used cover a period from 2000 to 2005 , the empirical analysis may also help us assess the impact of Poland's 2004 EU accession on the changes in ranking of importance of the sectors. The research is conducted in the framework of the so-called key sector analysis, which is based on the entropy theory. A crucial work on entropy decomposition analysis that provides a useful way of examining errors or changes in input-output structures was published by Henri Theil in the mid $60 s^{4}$. This approach allows us to decompose changes in the output into a set of additive components. Key sector analysis provides empirical evidence regarding the economic structure of sectors within an economy ${ }^{5}$. In general, the main goal of this type of analysis is to identify the sectors that have the greatest effects on the rest of the economy. In addition, the most important coefficients of input-output matrix may also be identified.

The key sector analysis often refers to the so-called multiplier product matrix $(\mathrm{MPM})^{6}$. By means of such a matrix, the probable future course of the economic structure of a country under study can be identified. The dynamics of the entries in the input-output matrix reflect the interaction of the different firm strategies towards innovation, for example. As one can see, the knowledge of key sectors is important for many reasons. Besides general policy implications, such knowledge is useful in updating and forecasting procedures of input matrices where

3 Professor Leszek Balcerowicz is a former Deputy Prime Minister and Minister of Finance and former President of the National Bank of Poland (NBP). He is one of the main architects of Poland's economic reforms initiated in 1989.

4 See Theil (1967).

5 See e.g. Chenery and Watanabe (1958), Hewings and Romanos (1981), Hewings (1982), Defourny and Thorbecke (1984), Białas and Gurgul (1998).

6 The interpretation of the elements of this matrix is strongly related to the so-called maximum entropy criterion, which gives us the opportunity to analyze various aspects of sectorial interdependences in a static Input-Output model. We will provide more details on maximum entropy decomposition in Section 3. 
Key sectors after a decade of transition: Evidence from Poland

early identification of key sectors is crucial for the choice of an adequate method and more-precise approximation.

When focusing on the transition process, one has also take into account that this process has affected the basic principles of collecting social statistics by the central statistical offices in all CEE economies, especially with respect to the compilation of input-output (IO) tables. Before the beginning of the transition, such tables were compiled according to the material product system (MPS). From 1995 onward, the process of constructing IO tables has followed the system of national accounts (SNA) which, in general, is typical for all market economies. Since MPS- and SNA-based tables are uncomparable and attempts of conversion from MPS into SNA are, in general, not successful, we focus solely on the reliable IO data on Poland constructed according to the SNA in this paper.

The motivation to perform an examination of key sectors in the case of Poland is twofold. First, in the case of any economy, the identification and classification of such influential fields might provide the basis for taxonomy of the economy as well as contribute to enriching our understanding of the growth and the development processes (Ćmiel and Gurgul, 2002). In the case of European transition economies, however, such an analysis may also provide crucial information on the structural change of an economy during the process of economic transformation. Poland is the largest post-communist country in Central Europe and started the transition process as the first country in this region. Therefore, it is one of the economic and political leaders in the region. Second, in the case of Poland, such an examination based on post-communist data taken from more than one IO table has never been conducted (to the best of our knowledge). This way, our paper fills a gap in the literature, providing the results that may turn out to be important for both researchers and policymakers in Poland (as well as other CEE transition economies).

The content of this paper is as follows. In Section 2, the discussion on methodological questions in respect to the identification and examination of key sectors is showed. Section 3 presents research hypotheses examined in this paper. The dataset and main empirical results are provided in Section 4. Finally, in Section 5, we summarize the major findings and suggest directions for future research.

\section{Research methodology}

\subsection{Principles of key sector analysis}

In order to shed some light on the MPM-based approach, let us focus on the well-known static IO model (Ćmiel and Gurgul, 1996a, 1996b, 1997) given by the equation (1). 
This equation takes the form:

$$
\mathbf{y}=(\mathbf{I}-\mathbf{A}) \mathbf{x}
$$

where $\mathrm{A}=\left[a_{i j}\right]_{i, j=1, \ldots, n}$ denotes an $n \times n$ IO matrix, $\mathbf{x}$ stands for the output vector, and $y$ denotes the final demand vector (both of dimension $n \times 1$ ). From equation (1) one gets:

$$
\mathbf{x}=(\mathbf{I}-\mathbf{A})^{-1} \mathbf{y}=\mathbf{B y}
$$

where $\mathbf{B}=\left[b_{i j}\right]_{i, j=1, \ldots, n}$. Let us define the row and column multipliers:

$$
\begin{gathered}
B_{i \bullet}=\sum_{j=1}^{n} b_{i j} \quad \text { the } i \text {-th row multiplier } \\
B_{\bullet j}=\sum_{i=1}^{n} b_{i j} \quad \text { the } j \text {-th column multiplier }
\end{gathered}
$$

As underlined by Sonis and Hewings (1989), the input-output multiplier matrix (MPM) is given by the formula:

$$
\mathbf{M}=\frac{1}{V}\left[B_{i \bullet} B_{\bullet j}\right]=\frac{1}{V}\left[\begin{array}{c}
B_{1 \bullet} \\
B_{2 \bullet} \\
\vdots \\
B_{n \bullet}
\end{array}\right]\left[B_{\bullet 1}, B_{\bullet 2}, \ldots, B_{\bullet n}\right]=\left[m_{i j}\right]_{i, j=1, \ldots, n}
$$

where $V=\sum_{i=1}^{n} \sum_{j=1}^{n} b_{i j}$.

The structure of the MPM reflects the properties of the sectoral backward and forward linkages. Let $B_{\bullet} j_{0}$ represent the largest column multiplier and $B_{i_{0}}$ • stand for the largest row multiplier. The element of matrix $\mathbf{M}$ located at position $\left(i_{0}, j_{0}\right)$ given by the formula:

$$
m_{i_{0} j_{0}}=\frac{1}{V} B_{i_{0}} \bullet B_{\bullet} j_{0}
$$

is called the largest cross. After the exclusion of row $i_{0}$ and $j_{0}$ from matrix $\mathbf{M}$, the second largest cross can be found, and so on. The number of crosses identified this way is equal to the rank of the MPM. Following Rasmussen (1956), for each sector $j$ of an economy, two types of indices of the Leontief inverse may be defined: the so-called backward linkage, defined as: 


$$
B L_{j}=\frac{\frac{1}{n} \sum_{i=1}^{n} b_{i j}}{\frac{1}{n^{2}} \sum_{i, j=1}^{n} b_{i j}}=\frac{n B_{\bullet j}}{V}
$$

and the forward linkage, defined below:

$$
F L_{i}=\frac{\frac{1}{n} \sum_{j=1}^{n} b_{i j}}{\frac{1}{n^{2}} \sum_{i, j=1}^{n} b_{i j}}=\frac{n B_{i \bullet}}{V}
$$

Both of these measures have important and rather straightforward economic interpretation. A backward linkage greater than $1\left(B L_{j}>1\right)$ implies that a unit change in final demand in sector $j$ will create an abnormal increase in activity in the whole economy. Similarly, if the forward linkage is greater than $1\left(F L_{j}>1\right)$, then a unit change in the final demand in all sectors will create more than an average increase in sector $j$ (Ćmiel and Gurgul, 2002). Taking into account the possible values of $B L_{j}$ and $F L_{j}$ we can define four types of sectors in the Polish economy:

Definition 1. Sector $j$ is called $a$ :

- key sector if $F L_{j}>1$ and $B L_{j}>1$,

- forward-linkage-oriented if $F L_{j}>1$ and $B L_{j}<1$,

- backward-linkage-oriented if $F L_{j}<1$ and $B L_{j}>1$,

- weak-oriented $F L_{j}<1$ and $B L_{j}<1$.

This definition provides a simple tool that can be used in the process of classifying the sectors of an economy.

\subsection{Maximum entropy decomposition}

To shed some light on the concept of entropy in statistical mechanics, we may restrict our discussion to the case of a discrete probabilistic space $\left\{\left(x_{i}, p_{i}\right)\right\}_{i \in I}{ }^{7}$. The set of probabilities $p_{i}$ provides a precise description of the randomness in the system. Since the number of possible states in almost any economic system is very high, the usefulness of this set becomes significantly reduced. In other words, one seeks the quantity that would be a function of the probabilities $p_{i}$

7 Although the concept of entropy was originally a thermodynamic construct, it has been adapted in other fields of science, including economics. 
and give an appropriate measure of the randomness of a system. The entropy defined as:

$$
H:=-\sum_{i \in I} p_{i} \ln p_{i}
$$

is an example of such a measure. Looking at entropy from the perspective of statistical mechanics, it seems reasonable to interpret it as a measure of the number of ways in which a system may be arranged - a measure of the "disorder" (the higher the entropy, the higher the disorder) ${ }^{8}$.

A simple application of the Shannon information inequality helps us prove that the matrix $\mathbf{M}$ defined in equation (5) has the so-called property of maximum entropy in the class of all matrices with fixed marginals ${ }^{9}$. As a consequence, this matrix may represent the most homogenous distribution of the components of the column and row multipliers of the Leontief inverse $\mathbf{B}$ representing total inputs. The economic interpretation of the MPM matrix is related to the equalization tendency of total inputs in an economy. In other words, approximately the same profit rates can be obtained from given investments in particular sectors.

Matrix $\mathbf{M}$ allows us to conduct a decomposition of a Leontief inverse, which has an important economic interpretation. Let $\operatorname{diag}(\mathbf{X})$ denote the diagonal of square matrix $\mathbf{X}$. If one defines:

$$
\begin{gathered}
\mathbf{D}:=\operatorname{diag}(\mathbf{B}-\mathbf{M}) \\
\mathbf{R}:=\mathbf{B}-\mathbf{M}-\mathbf{D} \\
\mathbf{S}:=\frac{1}{2}\left(\mathbf{R}+\mathbf{R}^{\mathrm{T}}\right) \\
\mathbf{S}_{\mathrm{a}}:=\frac{1}{2}\left(\mathbf{R}-\mathbf{R}^{\mathrm{T}}\right),
\end{gathered}
$$

then:

$$
\mathbf{R}=\frac{1}{2}\left(\mathbf{R}+\mathbf{R}^{\mathrm{T}}\right)+\frac{1}{2}\left(\mathbf{R}-\mathbf{R}^{\mathrm{T}}\right)=\mathbf{S}+\mathbf{S}_{\mathrm{a}}
$$

As a consequence, one may write the following maximum entropy decomposition of the Leontief inverse:

$$
\mathbf{B}=\mathbf{M}+\mathbf{D}+\mathbf{S}+\mathbf{S}_{\mathrm{a}}
$$

Here, $\mathbf{M}$ stands for the maximum entropy tendency, and the diagonal matrix $\mathbf{D}$ represents the so-called additional sectoral scale effects. Symmetric matrix $\mathbf{S}$ and asymmetric matrix $\mathbf{S}_{\mathrm{a}}$ (both with null diagonal) reflect the symmetric and asymmetric tendencies, respectively.

8 See Sethna (2006).

9 A formal mathematical proof of this statement is presented in the Appendix at the end of this paper. 


\subsection{Sensitivity testing}

Another important feature of the MPM is the possibility of applying this matrix in an analysis of the sensitivity of Leontief inverse $\mathbf{B}$ to the perturbation of one component of direct coefficient matrix $\mathbf{A}$. Such an approach provides a basis to determine the most important coefficients of $\mathbf{A}$; i.e., such coefficients where a small change in their values leads to largest relative change of the elements of matrix $\mathbf{B}$.

To shed some light on this concept, for each $i_{0}, j_{0} \in\{1, . ., n\}$ define the socalled first order field of influence of change of the form:

$$
\mathbf{F}\left(i_{0}, j_{0}\right)=\left[\begin{array}{c}
b_{1 i_{0}} \\
b_{2 i_{0}} \\
\vdots \\
b_{n i_{0}}
\end{array}\right]\left[b_{j_{0} 1}, b_{j_{0} 2}, \ldots, b_{j_{0} n}\right]=\left[b_{i i_{0}} b_{j_{0} j}\right]_{i, j=1, \ldots, n}
$$

The economic interpretation of matrix $\mathbf{F}\left(i_{0}, j_{0}\right)$ follows from the ShermanMorrison (1950) formula ${ }^{10}$. The latter allows examining the changes of entries in matrix $\mathbf{B}$ after a change in one element of matrix $\mathbf{A}$ takes place. If the change of the size $\varepsilon$ occurs in position $\left(i_{0}, j_{0}\right)$ in matrix $\mathbf{A}$; i.e., element $a_{i_{0}, j_{0}}$ changes to $(1+\varepsilon) a_{i_{0}, j_{0}}$ (denote this transformation of matrix $\mathbf{A}$ as $\left.\mathbf{A}_{\varepsilon\left(i_{0}, j_{0}\right)}\right)$, then the following Sherman-Morrison formula holds true:

$$
\mathbf{B}_{\varepsilon\left(i_{0}, j_{0}\right)}-\mathbf{B}=\frac{\varepsilon}{1-b_{j_{0} i_{0}}} \mathbf{F}\left(i_{0}, j_{0}\right)
$$

where $\mathbf{B}_{\varepsilon\left(i_{0}, j_{0}\right)}=\left(I-\mathbf{A}_{\varepsilon\left(i_{0}, j_{0}\right)}\right)^{-1}=\left[b_{k, l}^{\varepsilon\left(i_{0}, j_{0}\right)}\right]_{k, l=1, \ldots, n}$. The sum of all elements of the matrix $\mathbf{F}\left(i_{0}, j_{0}\right)$ is given by the following formula:

$$
S\left(\mathbf{F}\left(i_{0}, j_{0}\right)\right)=\sum_{1 \leq i, j \leq n} b_{i i_{0}} b_{j_{0} j}=B_{\bullet i_{0}} B_{j_{0}} \bullet
$$

Therefore, we have:

$$
\mathbf{M}=\frac{1}{V}[S(\mathbf{F}(j, i)]
$$

The presented formulas allow us to investigate the importance of direct inputs and, thus, the impact of the coefficients of $\mathbf{A}$ on $\mathbf{B}=(\mathbf{I}-\mathbf{A})^{-1}$. More precisely, to measure the sensitivity of the Leontief inverse to the change of the value of element $a_{i_{0}, j_{0}}$, we apply the formula (14) to obtain the matrix of differences

10 See Sonis and Hewings $(1989,1992)$. 
between the initial and modified Leontief inverses. Next, we obtain relative inverse error matrix $\mathbf{R} \mathbf{I}_{\varepsilon\left(i_{0}, j_{0}\right)}$, defined as:

and its norm:

$$
\mathbf{R I}_{\varepsilon\left(i_{0}, j_{0}\right)}=\left[\frac{b_{k, l}^{\varepsilon\left(i_{0}, j_{0}\right)}-b_{k, l}}{b_{k, l}}\right]_{k, l=1, \ldots, n}
$$

$$
\left\|\mathbf{R I}_{\varepsilon\left(i_{0}, j_{0}\right)}\right\|=\sum_{b_{k, l} \neq 0}\left|\frac{b_{k, l}^{\varepsilon\left(i_{0}, j_{0}\right)}-b_{k, l}}{b_{k, l}}\right|
$$

We compute the norms defined in (18) for all possible choices of $\left(i_{0}, j_{0}\right)$. As a consequence, we obtain the sensitivity matrix defined as:

$$
\mathbf{S}_{\varepsilon}=\left[\left\|\mathbf{R I}_{\varepsilon\left(i_{0}, j_{0}\right)}\right\|\right]_{i_{0}, j_{0}=1, \ldots, n}
$$

Finally, we assign ranks in descending order for the elements of this matrix. The first rank was assigned to the most sensitive element (according to the relative change of the Leontief inverse) of matrix $\mathbf{A}$; i.e., the relative change of this element has the greatest effect on $\mathbf{B}$.

\section{Research hypotheses}

In general, each research hypothesis examined in this paper consists of four major components. In the first part of each conjecture, we refer to the classification presented in Definition 1. Next, we express our suppositions on the dynamics of the multiplier product matrix over the period under study. In the third steep, we examine the issue of sensitivity; i.e., we focus on the most important coefficients on the matrix of direct inputs. In the last step, we refer to the dynamics of indices of additional scale effects.

As previously mentioned, it is easy to note the lack of extensive research on key sectors in Poland, especially with respect to the transition data. In one of the very few papers devoted to the analysis of key sectors in Poland, Ćmiel and Gurgul (2002) examined MPS-compiled input-output tables from the pretransition period and provided some evidence in favor of the hypothesis that, other than heavy industry, the food-and-agriculture-related sectors played the role of key sectors before the beginning of the transition. It seems interesting to test whether these observations would also remain true after the application of SNA-based IO tables constructed on the basis of the data from the second decade of the transition period. Moreover, one may expect that the Polish economy was 
Key sectors after a decade of transition: Evidence from Poland

confronted with new regulations after EU accession, including the common EU agricultural policy (which, in particular, could have had a significant negative impact on the role of the discussed sectors). Both of these conjectures may be examined by checking the following:

Hypothesis 1. Food-and-agriculture-related sectors - still key, but losing importance:

A. In the period under study, the food-and-agriculture-related sectors, including the sector of Agriculture and bunting products as well as the sector of Food and beverages, preserved the status of key sectors in Poland.

B. However, their importance was falling in context of both forward-as well as backward-linkages.

C. In general, the inverse sensitivity of food-and-agriculture-related sectors declined.

D. In general, the additional scale effects of food-and-agriculture-related sectors declined.

In the literature, it is often stressed that one of the major features of the economies of CEE in the 90s was the process of de-industrialization, leading to heavy losses in the secondary sector of the economy and redirecting the economic activity in these countries to other sectors, especially services (Kalvet and Kattel, 2006). The latter was accompanied with the ongoing process of globalization, especially in the sphere of economic openness and information flow, which had a significant positive causal impact on economic growth in CEE transition economies, including Poland ${ }^{11}$. It seems interesting to test whether both of these processes also continued in the period of EU accession. For this purpose, one should verify the following:

Hypothesis 2. Transformation from manufacturing towards services:

A. Taking into account the linkages-based indicators of sectorial importance, the manufacturing sectors of Poland (especially metallurgy-, textiles-, chemical-, and mining-related ones) did not play the role of key sectors in Poland during the period between 2000 and 2005. On the other hand, one could formulate an opposite conclusion with respect to the services-related sectors.

B. The manufacturing (services-related) sectors were derailing (rising in importance) in context of both forward as well as backward linkages.

C. In general, the inverse sensitivity of manufacturing (services-related) sectors bas declined (increased).

11 See Gurgul and Lach (2014). 
D. In general, the additional scale effects of manufacturing (services-related) sectors declined (increased).

One may claim that, during the period of transition, some sectors of CEE economies have grown dramatically (especially after EU accession). In the case of Poland, the inflow of EU structural funds had a stimulating impact on the development of the sector of construction, especially in the sphere of public infrastructure. Furthermore, from the beginning of the transition, Poland started to reorganize its financial market and open it to foreign capital, which caused a continuous rise in importance of the financial sector ${ }^{12}$. At the same time, not only could more Poles freely travel abroad, but the tourist offer of Poland has also been continuously expanding. These facts seem to constitute the background for the formulation of the following hypothesis:

Hypothesis 3. Sectors related to construction, finance, tourism, and traveling - even more important after EU accession:

A. In the period of 2000-2005, the sector of Construction as well as the financial-sphere-related sectors (e.g., Financial Intermediation, Real Estate Activities, Trade) and transport-and tourism-oriented sectors kept the status of key sectors in Poland.

B. The above-mentioned sectors were rising in importance in context of both forward as well as backward linkages.

C. The inverse sensitivity of the above-mentioned sectors increased.

D. The additional scale effects of the above-mentioned sectors increased.

The hypotheses listed above will be verified using the methodology presented in Section 2. In the next section, we present the dataset as well as the main empirical findings.

\section{Dataset and empirical results}

In this paper, we use the dataset comprising two highly-disaggregated national IO tables at basic prices ${ }^{13}$ provided by The Central Statistical Office (CSO) in Poland. The IO tables were constructed based on data from the years 2000 and 2005. Each table has dimensions of $55 \times 55$ Each table was published approximately 5 years after the reference year. Hence, in this paper, we focus on the

12 See e.g., Gurgul and Lach (2013).

13 The basic price is the most fundamental cost of a good or service to a consumer that does not include common extra fees (e.g. taxes). 
Key sectors after a decade of transition: Evidence from Poland

longest period available at the time of conducting the calculations, since the CSO in Poland has not constructed any IO table at basic prices for years before 2000 . Both national IO tables are published in current prices, expressed in thousands of Polish Zloty.

\subsection{Key sector analysis}

In the first step, we calculate the forward and backward linkages for all sectors of the Polish economy (see equations (7), (8), and Definition 1). Besides the detailed results for the year 2000, we also present the percentage change of forward $(\triangle F L)$ and backward $(\triangle B L)$ linkages in 2005 with respect to 2000 (see Table 1). This way, we are able to shed some light on the dynamics of the both types of indicators over the period between 2000 and 2005. The sectors of the Polish economy have been divided into four categories according to the criteria presented in Definition $\mathbf{1}^{14}$.

As one can see, the results presented in Table 1 provide only partial evidence in favor of the hypotheses formulated in Section 3. One can notice that the foodand-agriculture-related sectors (including the sectors of Agriculture and bunting products and of Food and beverages) preserved the status of key sectors in Poland, which supports Hypothesis $1 \mathrm{~A}^{15}$. However, the sectors of Tobacco products and Fishing products were classified as backward-linkage-oriented and weak-oriented sectors, respectively. In general, the importance of food-and-agriculturerelated sectors in context of both forward as well as backward linkages declined (around a 10\% drop in forward linkages; an over 30\% drop of backward linkage in the case of the sector of Fishing products), which provides support in favor of Hypothesis 1B.

When turning to the manufacturing sphere, one can formulate the group of sectors which kept the status of key sectors in 2000 and 2005; e.g., the sectors of Basic metals, Metal products, and Rubber and plastic products. This finding contradicts Hypothesis 2A. On the other hand, the sectors of Coal and peat, Crude oil and natural gas, metal ores, other mining products, and Chemicals and chemical products were classified only as forward-linkage-oriented sectors.

14 Since we deal with more than one IO table, for each sector we first calculated the average of forward and backward linkages in year 2000 and 2005. Next, we applied the Definition 1 to the averages of the linkages.

15 When analyzing the empirical findings, one should refer to the three hypotheses formulated in the previous section. To increase the readability of this section, let us recall the headings of the hypotheses: Hypothesis 1. Food-and-agriculture-related sectors - still key ones, but losing importance.

Hypothesis 2. Transformation from manufacture towards services.

Hypothesis 3. Sectors related to construction, finance, tourism and traveling - even more important after EU accession. 
Table 1

The results of key sector analysis in Poland based on 2000 and 2005 IO tables s, b, c $^{2}$

PART A: KEY SECTORS

\begin{tabular}{|c|c|c|c|c|c|c|}
\hline SECTOR NAME & $\begin{array}{c}2000 \\
\text { status }\end{array}$ & $\begin{array}{c}2005 \\
\text { status }\end{array}$ & $\begin{array}{l}F L \text { in } \\
2000\end{array}$ & $\Delta F L$ & $\begin{array}{l}B L \text { in } \\
2000\end{array}$ & $\Delta B L$ \\
\hline $\begin{array}{l}\text { Agriculture and bunting } \\
\text { products }\end{array}$ & $\mathbf{K}$ & $\mathbf{K}$ & 1.400 & $-9.71 \%$ & 1.208 & $-9.85 \%$ \\
\hline Food and beverages & $\mathbf{K}$ & $\mathbf{K}$ & 1.353 & $-8.28 \%$ & 1.390 & $-0.07 \%$ \\
\hline Paper and paper products & $\mathbf{K}$ & $\mathbf{K}$ & 1.221 & $-1.23 \%$ & 1.030 & $3.79 \%$ \\
\hline $\begin{array}{l}\text { Coke, refined petroleum } \\
\text { products }\end{array}$ & $\mathbf{K}$ & $\mathbf{K}$ & 1.216 & $2.22 \%$ & 1.054 & $0.00 \%$ \\
\hline Rubber and plastic products & $\mathbf{F}$ & $\mathbf{K}$ & 1.080 & $9.91 \%$ & 0.983 & $7.32 \%$ \\
\hline $\begin{array}{l}\text { Other non-metallic mineral } \\
\text { products }\end{array}$ & $\mathbf{K}$ & $\mathbf{K}$ & 1.046 & $-0.96 \%$ & 1.082 & $3.42 \%$ \\
\hline Basic metals & $\mathbf{K}$ & $\mathbf{K}$ & 1.616 & $1.61 \%$ & 1.151 & $-11.03 \%$ \\
\hline Metal products & $\mathbf{K}$ & $\mathbf{K}$ & 1.145 & $7.51 \%$ & 1.067 & $2.81 \%$ \\
\hline $\begin{array}{l}\text { Electricity, gas, steam and bot } \\
\text { water }\end{array}$ & $\mathbf{K}$ & $\mathbf{K}$ & 1.627 & $-7.19 \%$ & 1.167 & $-0.34 \%$ \\
\hline Construction work & $\mathbf{K}$ & $\mathbf{K}$ & 1.450 & $4.21 \%$ & 1.200 & $4.17 \%$ \\
\hline $\begin{array}{l}\text { Wholesale and commission } \\
\text { trade services }\end{array}$ & $\mathbf{F}$ & $\mathbf{K}$ & 2.258 & $-21.04 \%$ & 0.919 & $19.26 \%$ \\
\hline $\begin{array}{l}\text { Land and pipeline transport } \\
\text { services }\end{array}$ & $\mathbf{F}$ & $\mathbf{K}$ & 1.749 & $2.80 \%$ & 0.991 & $9.89 \%$ \\
\hline $\begin{array}{l}\text { Post and telecommunications } \\
\text { services }\end{array}$ & $\mathbf{K}$ & $\mathbf{K}$ & 1.352 & $-4.88 \%$ & 1.081 & $-4.16 \%$ \\
\hline $\begin{array}{l}\text { Financial intermediation } \\
\text { services }\end{array}$ & $\mathbf{K}$ & $\mathbf{F}$ & 1.515 & $-30.10 \%$ & 1.568 & $-41.65 \%$ \\
\hline Other business services & $\mathbf{K}$ & $\mathbf{K}$ & 2.438 & $9.97 \%$ & 1.041 & $0.77 \%$ \\
\hline
\end{tabular}


Key sectors after a decade of transition: Evidence from Poland

Table 1 cont.

PART B: FORWARD-LINKAGE-ORIENTED SECTORS

\begin{tabular}{|l|c|c|c|c|c|c|}
\hline \multicolumn{1}{|c|}{ SECTOR NAME } & $\begin{array}{c}2000 \\
\text { status }\end{array}$ & $\begin{array}{c}2005 \\
\text { status }\end{array}$ & $\begin{array}{c}F \boldsymbol{F} \text { in } \\
2000\end{array}$ & $\mathbf{F L}$ & $\begin{array}{c}\boldsymbol{F L} \text { in } \\
\mathbf{2 0 0 0}\end{array}$ & $\Delta \boldsymbol{B L}$ \\
\hline Coal and peat & $\mathbf{F}$ & & 1.077 & $-12.53 \%$ & 0.923 & $-2.49 \%$ \\
\hline $\begin{array}{l}\text { Crude oil and natural gas, } \\
\text { metal ores, } \\
\text { other mining products }\end{array}$ & $\mathbf{F}$ & $\mathbf{F}$ & 1.553 & $-2.51 \%$ & 0.654 & $-1.83 \%$ \\
\hline $\begin{array}{l}\text { Chemicals and chemical } \\
\text { products }\end{array}$ & $\mathbf{F}$ & $\mathbf{F}$ & 1.555 & $10.03 \%$ & 0.892 & $2.80 \%$ \\
\hline Machinery and equipment & $\mathbf{F}$ & $\mathbf{F}$ & 1.032 & $9.59 \%$ & 0.889 & $5.17 \%$ \\
\hline Sale and repair of vehicles & $\mathbf{K}$ & $\mathbf{F}$ & 1.185 & $-8.86 \%$ & 1.057 & $-15.89 \%$ \\
\hline Retail trade services & $\mathbf{F}$ & $\mathbf{F}$ & 1.008 & $18.25 \%$ & 0.931 & $2.15 \%$ \\
\hline
\end{tabular}

a $\mathbf{K}$ - key sector

$\mathbf{F}$ - forward-linkage-oriented sector

B - backward-linkage-oriented sector

- weak-oriented sector

b For each sector $\Delta F L(\Delta B L)$ denotes the difference between forward-(backward-) linkages in 2005 and 2000 .

$>10 \%$ rise $>10 \%$ drop

PART C: BACKWARD-LINKAGE-ORIENTED SECTORS

\begin{tabular}{|l|c|c|c|c|c|c|}
\hline \multicolumn{1}{|c|}{ SECTOR NAME } & $\begin{array}{c}2000 \\
\text { status }\end{array}$ & $\begin{array}{c}2005 \\
\text { status }\end{array}$ & $\begin{array}{c}\boldsymbol{F L} \text { in } \\
\mathbf{2 0 0 0}\end{array}$ & $\Delta \boldsymbol{F L}$ & $\begin{array}{c}\boldsymbol{F L} \text { in } \\
\mathbf{2 0 0 0}\end{array}$ & $\Delta \boldsymbol{B L}$ \\
\hline Forestry products & $\mathbf{B}$ & $\mathbf{B}$ & 0.903 & $-3.54 \%$ & 1.092 & $2.66 \%$ \\
\hline Tobacco products & $\mathbf{B}$ & $\mathbf{B}$ & 0.633 & $-6.32 \%$ & 1.134 & $4.14 \%$ \\
\hline Wearing apparel, furs & $\mathbf{B}$ & & 0.599 & $3.01 \%$ & 1.042 & $-6.62 \%$ \\
\hline Wood and products of wood & $\mathbf{B}$ & $\mathbf{B}$ & 0.919 & $-3.48 \%$ & 1.232 & $1.30 \%$ \\
\hline $\begin{array}{l}\text { Printed matter and recorded } \\
\text { media }\end{array}$ & $\mathbf{B}$ & $\mathbf{B}$ & 0.949 & $2.42 \%$ & 1.133 & $4.41 \%$ \\
\hline $\begin{array}{l}\text { Electrical machinery and } \\
\text { apparatus }\end{array}$ & & $\mathbf{B}$ & 0.938 & $1.07 \%$ & 0.976 & $5.02 \%$ \\
\hline
\end{tabular}


Table 1 cont.

PART C: BACKWARD-LINKAGE-ORIENTED SECTORS

\begin{tabular}{|c|c|c|c|c|c|c|}
\hline SECTOR NAME & $\begin{array}{c}2000 \\
\text { status }\end{array}$ & $\begin{array}{l}2005 \\
\text { status }\end{array}$ & $\begin{array}{l}F L \text { in } \\
2000\end{array}$ & $\Delta F L$ & $\begin{array}{l}F L \text { in } \\
2000\end{array}$ & $\Delta B L$ \\
\hline Motor vehicles & B & B & 0.821 & $16.32 \%$ & 1.036 & $8.30 \%$ \\
\hline Other transport equipment & B & B & 0.738 & $-5.28 \%$ & 1.058 & $-4.25 \%$ \\
\hline $\begin{array}{l}\text { Furniture, other manufactured } \\
\text { goods }\end{array}$ & B & B & 0.760 & $-2.24 \%$ & 1.119 & $7.77 \%$ \\
\hline $\begin{array}{l}\text { Recovered secondary raw } \\
\text { materials }\end{array}$ & B & $\mathbf{B}$ & 0.657 & $6.39 \%$ & 1.255 & $9.24 \%$ \\
\hline Hotel and restaurant services & $\mathbf{B}$ & $\mathbf{B}$ & 0.724 & $0.69 \%$ & 1.064 & $4.04 \%$ \\
\hline $\begin{array}{l}\text { Water and air transport } \\
\text { services }\end{array}$ & & B & 0.769 & $-11.31 \%$ & 0.975 & $9.13 \%$ \\
\hline $\begin{array}{l}\text { Supporting transport services; } \\
\text { tourism services }\end{array}$ & B & $\mathbf{B}$ & 0.881 & $13.17 \%$ & 1.081 & $18.50 \%$ \\
\hline $\begin{array}{l}\text { Services auxiliary to financial } \\
\text { intermed. }\end{array}$ & B & & 0.759 & $5.93 \%$ & 1.200 & $-27.67 \%$ \\
\hline Real estate services & B & $\mathbf{F}$ & 0.947 & $10.14 \%$ & 1.043 & $-7.38 \%$ \\
\hline $\begin{array}{l}\text { Recreational, cultural and } \\
\text { sport. services }\end{array}$ & $\mathbf{B}$ & $\mathbf{B}$ & 0.725 & $-2.90 \%$ & 1.070 & $-4.11 \%$ \\
\hline
\end{tabular}

a $\mathbf{K}$ - key sector

F - forward-linkage-oriented sector

B - backward-linkage-oriented sector

- weak-oriented sector

b For each sector $\Delta F L(\Delta B L)$ denotes the difference between forward-(backward-) linkages in 2005 and 2000 .

$>10 \%$ rise $>10 \%$ drop

PART D: WEAK-ORIENTED SECTORS

\begin{tabular}{|l|c|c|c|c|c|c|}
\hline \multicolumn{1}{|c|}{ SECTOR NAME } & $\begin{array}{c}2000 \\
\text { status }\end{array}$ & $\begin{array}{c}2005 \\
\text { status }\end{array}$ & $\begin{array}{c}F L \text { in } \\
2000\end{array}$ & $\Delta F L$ & $\begin{array}{c}B L \text { in } \\
2000\end{array}$ & $\Delta B L$ \\
\hline Fishing products & B & & 0.598 & $-1.84 \%$ & 1.137 & $-32.10 \%$ \\
\hline Textiles & & & 0.895 & $-1.01 \%$ & 0.844 & $0.00 \%$ \\
\hline
\end{tabular}


Key sectors after a decade of transition: Evidence from Poland

Table 1 cont.

\begin{tabular}{|c|c|c|c|c|c|c|}
\hline Leather and leather products & & & 0.648 & $-0.15 \%$ & 0.933 & $-7.07 \%$ \\
\hline $\begin{array}{l}\text { Office machinery and } \\
\text { computers }\end{array}$ & & & 0.647 & $2.32 \%$ & 0.646 & $12.07 \%$ \\
\hline $\begin{array}{l}\text { Radio, television and } \\
\text { communication equip. }\end{array}$ & & & 0.810 & $19.38 \%$ & 0.814 & $9.21 \%$ \\
\hline $\begin{array}{l}\text { Medical and optical } \\
\text { instruments }\end{array}$ & & & 0.618 & $0.81 \%$ & 0.872 & $-3.33 \%$ \\
\hline $\begin{array}{l}\text { Cold water and its } \\
\text { distribution }\end{array}$ & B & & 0.695 & $-3.88 \%$ & 1.058 & $-15.88 \%$ \\
\hline Insurance services & & & 0.663 & $-1.96 \%$ & 0.770 & $21.30 \%$ \\
\hline Renting services of machinery & $\mathbf{F}$ & & 1.006 & $-7.55 \%$ & 0.740 & $25.27 \%$ \\
\hline Computer and related services & & & 0.757 & $13.87 \%$ & 0.915 & $-3.83 \%$ \\
\hline $\begin{array}{l}\text { Research and development } \\
\text { services }\end{array}$ & & & 0.684 & $8.63 \%$ & 0.915 & $1.42 \%$ \\
\hline Public administration services & & & 0.561 & $32.98 \%$ & 0.784 & $1.79 \%$ \\
\hline Education services & & & 0.602 & $0.50 \%$ & 0.732 & $-0.14 \%$ \\
\hline Health services & & & 0.622 & $3.05 \%$ & 0.815 & $6.13 \%$ \\
\hline $\begin{array}{l}\text { Sewage and refuse disposal } \\
\text { services }\end{array}$ & & B & 0.804 & $0.87 \%$ & 0.911 & $15.37 \%$ \\
\hline $\begin{array}{l}\text { Membership organization } \\
\text { services }\end{array}$ & & $\mathbf{B}$ & 0.565 & $0.53 \%$ & 0.890 & $18.99 \%$ \\
\hline Other services & & & 0.671 & $-2.53 \%$ & 0.881 & $-9.53 \%$ \\
\hline $\begin{array}{l}\text { Private bousebolds with } \\
\text { employed persons }\end{array}$ & & & 0.558 & $0.54 \%$ & 0.558 & $29.39 \%$ \\
\hline
\end{tabular}

a $\mathbf{K}$ - key sector

F - forward-linkage-oriented sector

B - backward-linkage-oriented sector

- weak-oriented sector

b For each sector $\Delta F L(\Delta B L)$ denotes the difference between forward-(backward-) linkages in 2005 and 2000.

$>10 \%$ rise 
The analysis of the dynamics of forward and backward linkages of manufacturing sectors also leads to conclusions that are a bit ambiguous. In the case of the sectors of Basic metals and Coal and peat, one could notice significant drops in the backward and forward linkages (11\% and $12 \%$, respectively). This result, in turn, supports Hypothesis 2B. On the other hand, in the case of the sectors of Rubber and plastic products, Metal products and Chemicals and chemical products, the forward and backward linkages have increased (in some cases, even by $10 \%$ ).

In the case of the services-related sectors, one could list the following sectors that kept the status of key sectors: Wholesale and commission trade services, Land and pipeline transport services, Post and telecommunications services, Financial intermediation services, and Other business services. This fact clearly supports Hypothesis 2A. However, the results presented in Table 1 provide only weak evidence in favor of Hypothesis $2 \mathrm{~B}$, as the increase of forward and/or backward linkages was noticed only in the case of some of the above-mentioned sectors. The sectors of Construction and Financial intermediation services kept the status of key sectors, which supports Hypothesis 3B. Similar to the sectors of Land and pipeline transport services and Rubber and plastic products, the sector of Wholesale and commission trade services has changed its status from forward-linkage-oriented (2000) to a key sector (2005). However, in the case of the sector of Retail trade services (Tourism services), only forward (backward) linkages were found to be greater than one (which, in turn, weakens the evidence supporting Hypothesis 3A). In general, the analysis of the dynamics of forward and backward linkages provides rather-weak evidence in favor of Hypothesis $3 \mathrm{~B}$, as in the case of the sectors of Financial intermediation services, Wholesale and commission trade services, and Services auxiliary to financial intermediation. One could notice drops of forward and/or backward linkages, even of a size of $30-40 \%$. On the other hand, in the case of the sectors of Supporting transport services; tourism services and Retail trade services, both types of linkages increased during the period of 2000-2005.

\subsection{Sensitivity of the Leontief inverses}

In the next step, we examined the sensitivity of Leontief inverses over the analyzed period. For each year $t$, we calculate sensitivity matrix $S_{\varepsilon}^{t}$ using the equation (19) ${ }^{16}$. Next, we construct a matrix of ranks (denote it as $\mathrm{SM}_{\varepsilon}^{t}$ ) and reduced the maximal rank to the value of 50. This way, we obtain the restricted

16 In this paper, we proceed with $\varepsilon=0.01$, which corresponds to a one-percentage-point rise of one coefficient in matrix $\mathbf{A}$. We also examined the case of a one-percentage-point drop of one coefficient in matrix $\mathbf{A}(\varepsilon=-0.01)$. Since all results turned out to be robust to the choice of $\varepsilon$, we focus only on case $\varepsilon=0.01$. 
Key sectors after a decade of transition: Evidence from Poland

matrices of ranks denoted as $\mathrm{MSM}_{\varepsilon}^{t}{ }_{17}$. In the next step, we calculated the averaged sensitivity matrix defined as:

$$
\operatorname{MSM}_{\varepsilon}^{*}=\frac{1}{2}\left(\operatorname{MSM}_{\varepsilon}^{2000}+\operatorname{MSM}_{\varepsilon}^{2005}\right)
$$

and the matrix of directions and magnitudes of shifts between 2000 and 2005 defined as:

$$
\Delta \mathrm{MSM}_{\varepsilon}^{*}=\mathrm{MSM}_{\varepsilon}^{2005}-\mathrm{MSM}_{\varepsilon}^{2000}
$$

In Table 2, we present the top 59 most-sensitive coefficients of matrix $\mathrm{MSM}_{\varepsilon}^{*}$ along with the corresponding coefficients of matrix $\Delta \mathrm{MSM}_{\varepsilon}{ }^{18}$. Due to the large size of the IO tables, the presentation of the most-sensitive coefficients of the averaged sensitivity matrix was divided into four subsets.

Among the most important input-output coefficients, one could list those of Agriculture and hunting products used as input by Food and beverages (averaged rank: 4) or by itself (averaged rank: 13), coefficient of Food and beverages used as input by itself (averaged rank: 4.5) or by Agriculture and bunting products (averaged rank: 42), coefficient of Fishing products used as input by Food and beverages (average rank 39) and coefficient of Wholesale and commission trade services used as input by Food and beverages (average rank 40) and Agriculture and bunting products (averaged rank: 46.5). In general, most of the ranks of the above-mentioned coefficients increased during the period of 2000-2005, which may be interpreted as evidence of a decline of sensitivity of the Leontief inverse to the perturbation of the corresponding component of the direct coefficient matrix. This, in turn, provides some support in favor of Hypothesis 1C.

When turning to the manufacturing sectors, one can notice that the sensitivity ranks of the coefficient of Coal and peat used as input by Coke, refined petroleum products (averaged rank: 40.5), coefficient of Chemicals and chemical products used as input by itself (averaged rank: 26.5), coefficient of Rubber and plastic products used as input by itself (averaged rank: 47.5) or Land and pipeline transport services (averaged rank: 18) and coefficient of Metal products used as input by itself (averaged rank: 48) have declined, which corresponds to a rise of sensitivity and contradicts Hypothesis 2C.

17 The matrix $\mathrm{SM}_{\varepsilon}^{t}$ consists of numbers ranging from 1 to $55 \times 55=3025$. Due to space limitations, in the case of each Leontief's inverse, we focus on the 50 most sensitive coefficients. In other words, we define the restricted rank matrices in the following way: if $\mathrm{SM}_{\varepsilon}^{t}=\left[a_{k, l}^{t}\right]_{1 \leq k, l \leq 55}$ then $\operatorname{MSM}_{\varepsilon}^{t}=\left[b_{k, l}^{t}\right]_{1 \leq k, l \leq 55}$, where $b_{k, l}^{t}=\min \left(a_{k, l}^{t}, 50\right)$.

18 After restricting the Leontief's inverses in 2000 and 2005 to the top 50 elements, exactly 59 out of 3025 elements of the averaged matrix $\mathrm{MSM}_{\varepsilon}^{*}$ turned out to be smaller than 50 . 
Table 2

Top inverse sensitive coefficients of matrices of direct inputs in Poland based on 2000 and 2005 IO tables - the averaged rank and the change of the rank between 2000 and 2005 (in brackets)

PART A

\begin{tabular}{|c|c|c|c|c|c|c|c|c|c|c|c|}
\hline & 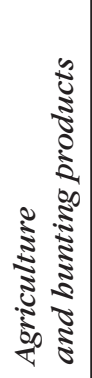 & 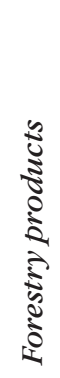 & 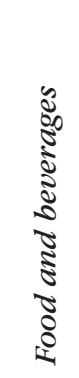 & 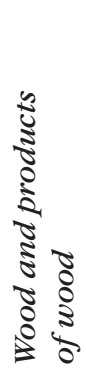 & 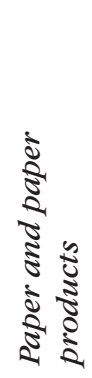 & 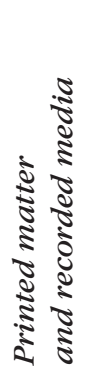 & 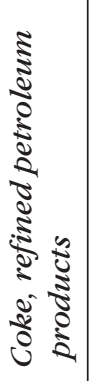 & 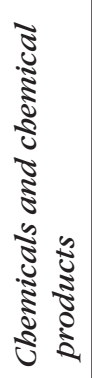 & 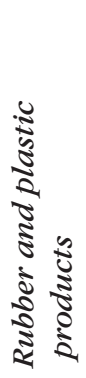 & 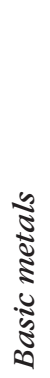 & 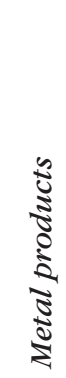 \\
\hline Agriculture and bunting products & $\begin{array}{l}13 \\
(5)\end{array}$ & & $\begin{array}{c}4 \\
(1)\end{array}$ & & & & & & & & \\
\hline Forestry products & & $\begin{array}{c}12 \\
(-1)\end{array}$ & & $\begin{array}{l}31.5 \\
(9.5)\end{array}$ & $\begin{array}{l}42.5 \\
(0.5)\end{array}$ & & & & & & \\
\hline Fishing products & & & $\begin{array}{c}39 \\
(11)\end{array}$ & & & & & & & & \\
\hline Coal and peat & & & & & & & $\begin{array}{c}40.5 \\
(-9.5)\end{array}$ & & & & \\
\hline $\begin{array}{l}\text { Crude oil and natural gas, metal ores, } \\
\text { other mining products }\end{array}$ & & & & & & & $\begin{array}{c}8 \\
(-1)\end{array}$ & & & & \\
\hline Food and beverages & $\begin{array}{c}42 \\
(-3)\end{array}$ & & $\begin{array}{c}4.5 \\
(-0.5)\end{array}$ & & & & & & & & \\
\hline
\end{tabular}


Table 2 cont.

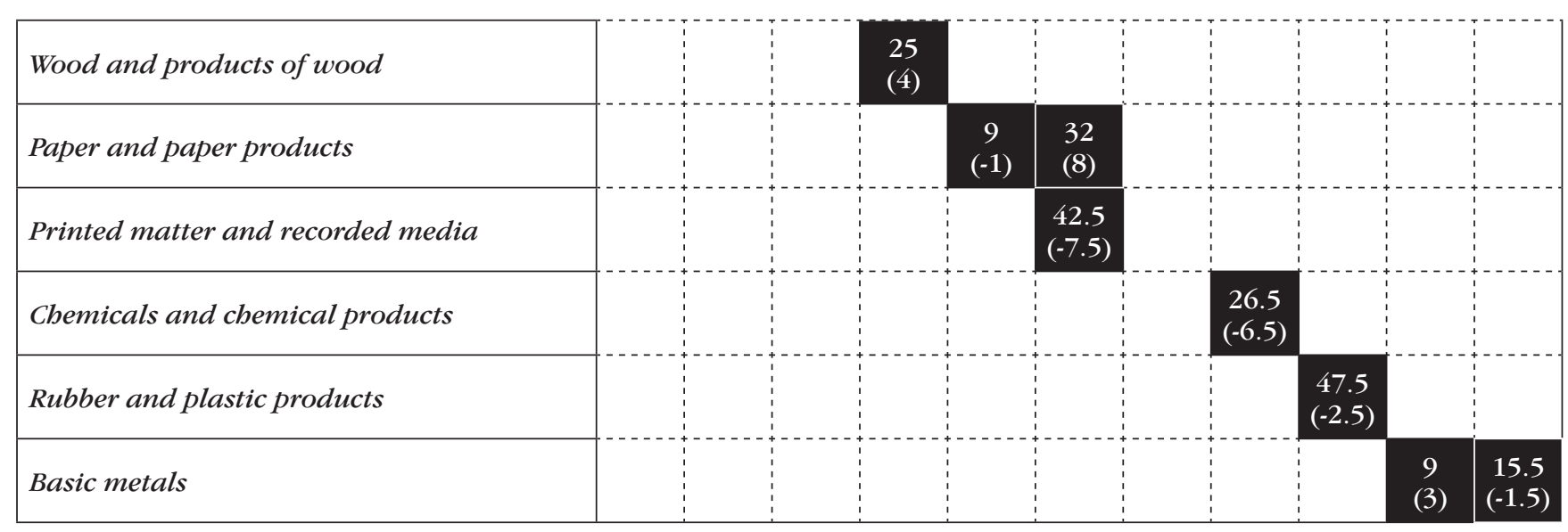

PART B

\begin{tabular}{|c|c|c|c|c|c|c|c|c|}
\hline & 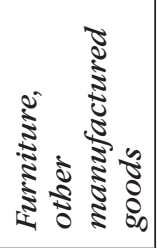 & 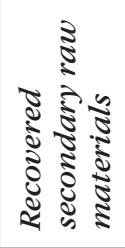 & 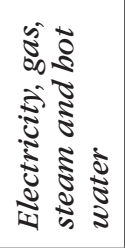 & 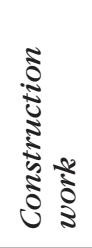 & 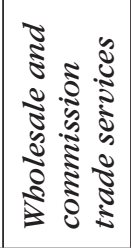 & 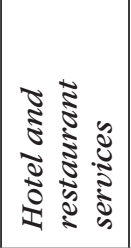 & 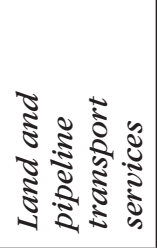 & 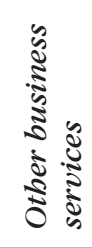 \\
\hline Coal and peat & & & $\begin{array}{l}2.5 \\
(0.5)\end{array}$ & & & & & \\
\hline $\begin{array}{l}\text { Crude oil and natural gas, metal ores, } \\
\text { other mining products }\end{array}$ & & & $\begin{array}{l}45 \\
(5)\end{array}$ & & & & & \\
\hline
\end{tabular}


Table 2 cont.

\begin{tabular}{|c|c|c|c|c|c|c|c|c|}
\hline & 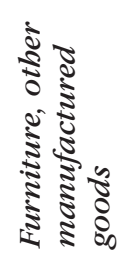 & 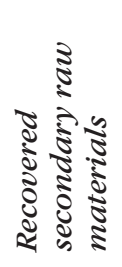 & 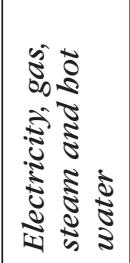 & 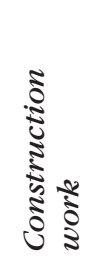 & 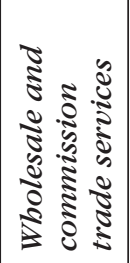 & 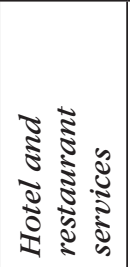 & 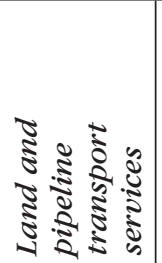 & 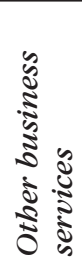 \\
\hline Food and beverages & & & & & $\begin{array}{c}33 \\
(-1)\end{array}$ & $\begin{array}{l}19.5 \\
(1.5)\end{array}$ & & \\
\hline Wood and products of wood & & & & & & $\begin{array}{c}11.5 \\
(-2.5)\end{array}$ & & \\
\hline Paper and paper products & $\begin{array}{l}41 \\
(9)\end{array}$ & & & & & & & \\
\hline Chemicals and chemical products & & & & & & & & $\begin{array}{c}37 \\
\text { (11) }\end{array}$ \\
\hline Rubber and plastic products & & & & & & & $\begin{array}{c}18 \\
(-5)\end{array}$ & \\
\hline Agriculture and bunting products & & & & $\begin{array}{l}41 \\
(-5)\end{array}$ & & & & \\
\hline Forestry products & & & & $\begin{array}{l}36.5 \\
(0.5)\end{array}$ & & & & \\
\hline Fishing products & & $\begin{array}{l}47 \\
\text { (3) }\end{array}$ & & & & & & \\
\hline
\end{tabular}


Table 2 cont.

\begin{tabular}{l} 
PART C \\
\cline { 2 - 6 }
\end{tabular}




\begin{tabular}{|c|c|c|c|c|c|}
\hline 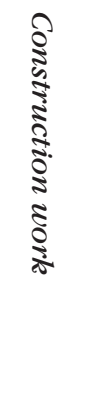 & 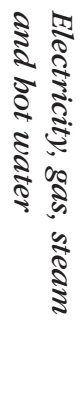 & 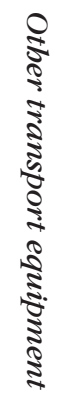 & 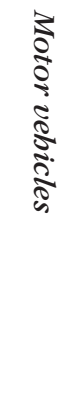 & 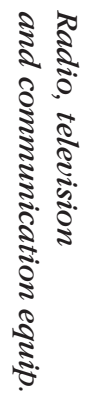 & \\
\hline $\mathbb{A} \sim$ & & & & & $\begin{array}{l}\text { Electricity, gas, steam } \\
\text { and bot water }\end{array}$ \\
\hline ثُ & & & & & Construction work \\
\hline & & & & & $\begin{array}{l}\text { Wholesale and commission } \\
\text { trade services }\end{array}$ \\
\hline & & $\begin{array}{l}\hat{0} \\
\dot{i}\end{array}$ & 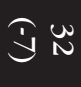 & & $\begin{array}{l}\text { Land and pipeline transport } \\
\text { services }\end{array}$ \\
\hline & & & & & Water and air transport services \\
\hline & & & & & $\begin{array}{l}\text { Supporting transport services; } \\
\text { tourism services }\end{array}$ \\
\hline & & & & 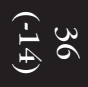 & $\begin{array}{l}\text { Post and telecom-munications } \\
\text { services }\end{array}$ \\
\hline & & & & & $\begin{array}{l}\text { Financial intermediation } \\
\text { services }\end{array}$ \\
\hline & & & & & $\begin{array}{l}\text { Services auxiliary } \\
\text { to financial intermed }\end{array}$ \\
\hline E & $\stackrel{N}{\sim}$ & & & & Real estate services \\
\hline હે & & & & & Other business services \\
\hline
\end{tabular}


Table 2 cont

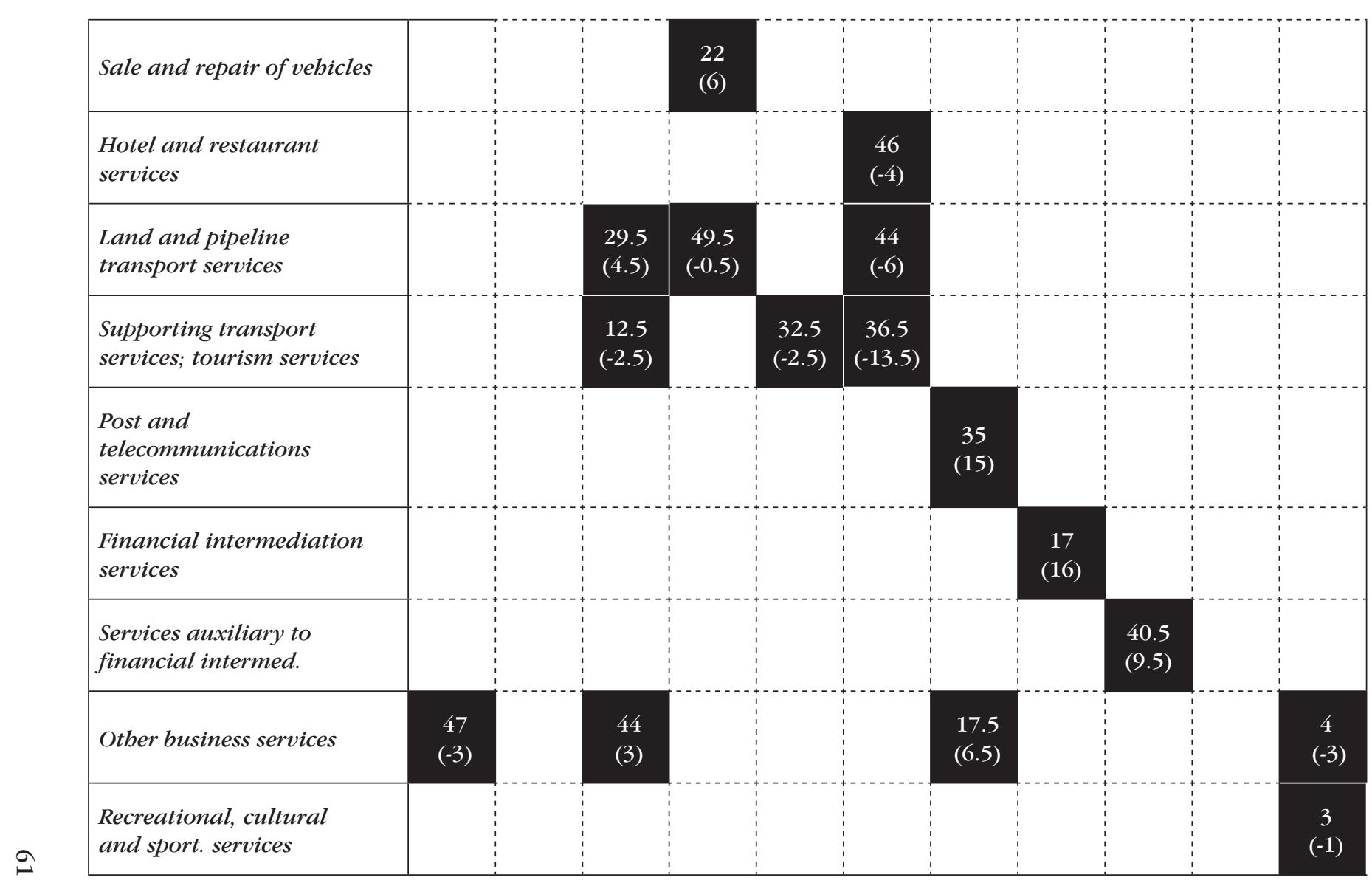


The evidence supporting Hypothesis 2C was rather weaker and was based (among others) on the visual inspection of the coefficient of Basic metals used as input by itself (average rank: 9) and Chemicals and chemical products used as input by Other business services (averaged rank: 37).

The sensitivity ranks of the coefficient of Construction work used as input by itself (average rank: 9) or by Other business services (averaged rank: 27), the coefficient of Supporting transport services; tourism services used as input by itself (average rank: 36.5) or Wholesale and commission trade services (average rank: 12.5), the coefficient of Recreational, cultural and sport services used as input by Other business services (average rank: 3), have declined, which corresponds to a rise of sensitivity and supports Hypothesis 3C. On the other hand, in the case of financial-sphere-related sectors, the sensitivity ranks of the respective coefficients (e.g., Financial intermediation services used as input by itself - averaged rank 17, Services auxiliary to financial intermediation used as input by itself - averaged rank: 40.5) have significantly increased, which clearly contradicts Hypothesis 3C.

\subsection{Maximal entropy decompositions}

We did not restrict ourselves to only an investigation of Leontief inverses, but we also examined in detail the behavior of matrices occurring in the decomposition (12). Let $\mathrm{X}^{t}$ denote any matrix from the list: D, S, Sa obtained for the year $t^{19}$. If $\mathrm{X}^{t}=\left[x_{k, l}^{t}\right]$ we may define:

$$
\mathrm{X}^{*}=\frac{1}{2}\left(\mathrm{X}^{2005}+\mathrm{X}^{2000}\right)
$$

and matrices of directions and percentage magnitudes of the 2000-2005 change as:

$$
\Delta \mathrm{X}^{*}=\left[\frac{x_{k, l}^{2005}-x_{k, l}^{2000}}{x_{k, l}^{2000}} \times 100 \%\right]
$$

Using equations (22) and (23), we obtained matrices $\mathrm{D}^{*}, \mathrm{~S}^{*}, \mathrm{Sa}^{*}$ and matrices $\Delta \mathrm{D}^{*}, \Delta \mathrm{S}^{*}, \Delta \mathrm{Sa}^{*}$. Table 3 presents the outcomes obtained after an analysis of the diagonal components of Leontief inverses in Poland over the period of 2000-2005.

19 We do not present detailed results regarding neither the individual nor averaged MPM matrices. From an economic point of view, direct interpretation of the elements of these matrices is not as straightforward as the interpretation of elements of the matrices defined in (10); i.e., additional scale effects (matrix D), symmetric balances (matrix S), and asymmetric imbalances (matrix Sa). 
Table 3

Analysis of the diagonal components of Leontief inverses ${ }^{\mathrm{a}}$

\begin{tabular}{|c|c|c|c|c|c|}
\hline \multicolumn{3}{|c|}{ Positive shift between 2000 and 2005} & \multicolumn{3}{|c|}{ Negative shift between 2000 and 2005} \\
\hline Sector name & $\begin{array}{c}\text { Average } \\
\text { diagonal } \\
\text { coefficient }\end{array}$ & $\begin{array}{c}\text { Shift } \\
\text { (descend- } \\
\text { ing) }\end{array}$ & Sector name & $\begin{array}{c}\text { Average } \\
\text { diagonal } \\
\text { coefficient }\end{array}$ & $\begin{array}{c}\text { Shift } \\
\text { (ascend- } \\
\text { ing) }\end{array}$ \\
\hline Motor vehicles & 1.175 & $8.80 \%$ & Financial intermediation services & 1.599 & $-43.20 \%$ \\
\hline $\begin{array}{l}\text { Radio, television and } \\
\text { communication equip. }\end{array}$ & 1.229 & $6.38 \%$ & $\begin{array}{l}\text { Services auxiliary to financial } \\
\text { intermediation }\end{array}$ & 1.151 & $-7.44 \%$ \\
\hline $\begin{array}{l}\text { Supporting transport services; } \\
\text { tourism services }\end{array}$ & 1.12 & $5.32 \%$ & Agriculture and hunting products & 1.266 & $-7.23 \%$ \\
\hline Recovered secondary raw materials & 1.111 & $3.85 \%$ & Tobacco products & 1.064 & $-7.16 \%$ \\
\hline Printed matter and recorded media & 1.113 & $3.47 \%$ & Basic metals & 1.196 & $-6.47 \%$ \\
\hline Machinery and equipment & 1.031 & $3.05 \%$ & $\begin{array}{l}\text { Post and telecommunications } \\
\text { services }\end{array}$ & 1.087 & $-5.02 \%$ \\
\hline Other business services & 1.099 & $2.86 \%$ & Cold water and its distribution & 1.056 & $-3.90 \%$ \\
\hline Metal products & 1.068 & $2.85 \%$ & Other transport equipment & 1.115 & $-2.83 \%$ \\
\hline Construction work & 1.157 & $2.80 \%$ & Water and air transport services & 1.039 & $-2.57 \%$ \\
\hline Research and development services & 1.095 & $2.59 \%$ & Sewage and refuse disposal services & 1.092 & $-2.26 \%$ \\
\hline Furniture, other manufactured goods & 1.033 & $2.55 \%$ & Retail trade services & 1.008 & $-1.96 \%$ \\
\hline Health services & 1.046 & $2.52 \%$ & Coal and peat & 0.995 & $-1.89 \%$ \\
\hline Rubber and plastic products & 1.085 & $2.43 \%$ & $\begin{array}{l}\text { Electricity, gas, steam and bot } \\
\text { water supply }\end{array}$ & 1.007 & $-1.87 \%$ \\
\hline Chemicals and chemical products & 1.122 & $2.25 \%$ & Paper and paper products & 1.236 & $-1.45 \%$ \\
\hline
\end{tabular}


Table 3 cont.

\begin{tabular}{|l|c|c|l|c|c|}
\hline \multicolumn{4}{|c|}{ Positive shift between 2000 and 2005 } & \multicolumn{2}{c|}{ Negative shift between 2000 and 2005 } \\
\hline $\begin{array}{c}\text { Sverage } \\
\text { diagonal } \\
\text { coefficient }\end{array}$ & $\begin{array}{c}\text { Shift } \\
\text { (descend- } \\
\text { ing) }\end{array}$ & $\begin{array}{c}\text { Average } \\
\text { diagonal } \\
\text { coefficient }\end{array}$ & $\begin{array}{c}\text { Shift } \\
\text { (ascend- } \\
\text { ing) }\end{array}$ \\
\hline Computer and related services & 1.079 & $2.25 \%$ & Fishing products & 1.022 & $-1.26 \%$ \\
\hline Textiles & 1.088 & $2.23 \%$ & Coke, refined petroleum products & 0.999 & $-1.19 \%$ \\
\hline Office machinery and computers & 1.035 & $2.05 \%$ & Leather and leather products & 1.097 & $-1.18 \%$ \\
\hline Land and pipeline transport services & 1.019 & $1.58 \%$ & Medical and optical instruments & 1.006 & $-1.09 \%$ \\
\hline $\begin{array}{l}\text { Wholesale and commission trade } \\
\text { services }\end{array}$ & 0.968 & $1.46 \%$ & Other services & 1.005 & $-0.99 \%$ \\
\hline Other non-metallic mineral products & 1.086 & $1.11 \%$ & Food and beverages & 1.238 & $-0.96 \%$ \\
\hline Electrical machinery and apparatus & 1.045 & $1.06 \%$ & Sale and repair of vehicles & 1.054 & $-0.85 \%$ \\
\hline $\begin{array}{l}\text { Recreational, cultural and sport. } \\
\text { services }\end{array}$ & 1.031 & $0.78 \%$ & Wearing apparel, furs & 0.992 & $-0.50 \%$ \\
\hline Wood and products of wood & 1.168 & $0.34 \%$ & Crude oil and natural gas, metal ores, & 0.981 & $-0.31 \%$ \\
\hline Hotel and restaurant services & 0.983 & $0.31 \%$ & Membership organization services & 0.982 & $-0.31 \%$ \\
\hline Education services & 1 & $0.20 \%$ & $\begin{array}{l}\text { Private households with employed } \\
\text { persons }\end{array}$ & 0.988 & $-0.30 \%$ \\
\hline Renting services of machinery & 1.052 & $0.19 \%$ & Real estate services & 0.992 & $-0.20 \%$ \\
\hline Public administration services & 0.986 & $0.10 \%$ & Insurance services & 0.988 & $-0.10 \%$ \\
\hline Forestry products & 1.293 & $0.08 \%$ & & &
\end{tabular}

a Shading was used to indicate 15 largest elements of the average of diagonal components of the Leontief's inverses for 2000 and 2005. 
Key sectors after a decade of transition: Evidence from Poland

It is worth to underline that, despite the fact that most of the food-and-agriculture-related sectors (e.g., Food and beverages, Agriculture and bunting products) were classified among the top 15 sectors with the largest averaged additional scale effects, one could observe a negative shift of the corresponding diagonal component of Leontief's inverse between 2000 and 2005, which clearly supports Hypothesis 1D. In general, the additional scale effects of most of the manufacturing sectors (especially the sector of Basic metals, but also the sectors of Coal and peat, Paper and paper products, Leather and leather products) declined, which in turn supports Hypothesis 2D. However, in the case of some sectors (e.g. Metal products, Furniture, other manufactured goods, Rubber and plastic products, Chemicals and chemical products ${ }^{20}$ ), one could observe a slight (2-2.85\%) increase of the additional scale effects. In case of the following coefficients of services-related sectors: Other business services, Health services, and Computer and related services, one could observe a positive shift of the corresponding diagonal component of Leontief's inverse, which supports Hypothesis 2D.

A positive shift was also noticed in the case of the sectors of Construction work and Supporting transport services; tourism services ${ }^{21}$. This result provided some evidence in favor of Hypothesis 3D. However, despite the fact that the sectors of Financial intermediation services and Services auxiliary to financial intermediation were both classified among the top 15 sectors with the largest averaged additional scale effects, one could observe extremely negative shifts of the corresponding diagonal component of Leontief's inverse between 2000 and 2005, which clearly contradicts Hypothesis 4D.

In the last stage of our empirical study, we supplement the previous results and provide some insights on the evolution of the symmetric and asymmetric components of Leontief's inverses of the Polish economy in years 2000 and 2005. In Table 4, the results of the analysis of symmetric components are presented. As mentioned earlier, such an analysis is reflected in the formulation of matrices $S^{*}$ and $\Delta S^{*}$. In order to present the results in a transparent way, we restrict the presentation only to the 15 largest (in terms of absolute value) upper triangular ${ }^{22}$ coefficients of matrix $\mathrm{S}^{*}$. In addition, the corresponding shifts (i.e., corresponding elements of matrix $\Delta S^{*}$ ) are also presented (in parentheses).

It is worth to underline that all of the averaged bilateral balances were found to be positive.

20 This sector was classified among 15 sectors with the largest averaged additional scale effects.

21 Both of these sectors turned out to be characterized by relatively large averaged additional scale effects.

22 Recall that, by definition, the matrices $S^{*}$ and $\Delta S^{*}$ are both symmetric with null diagonal. Therefore, we may focus only on lower or upper triangular elements. 


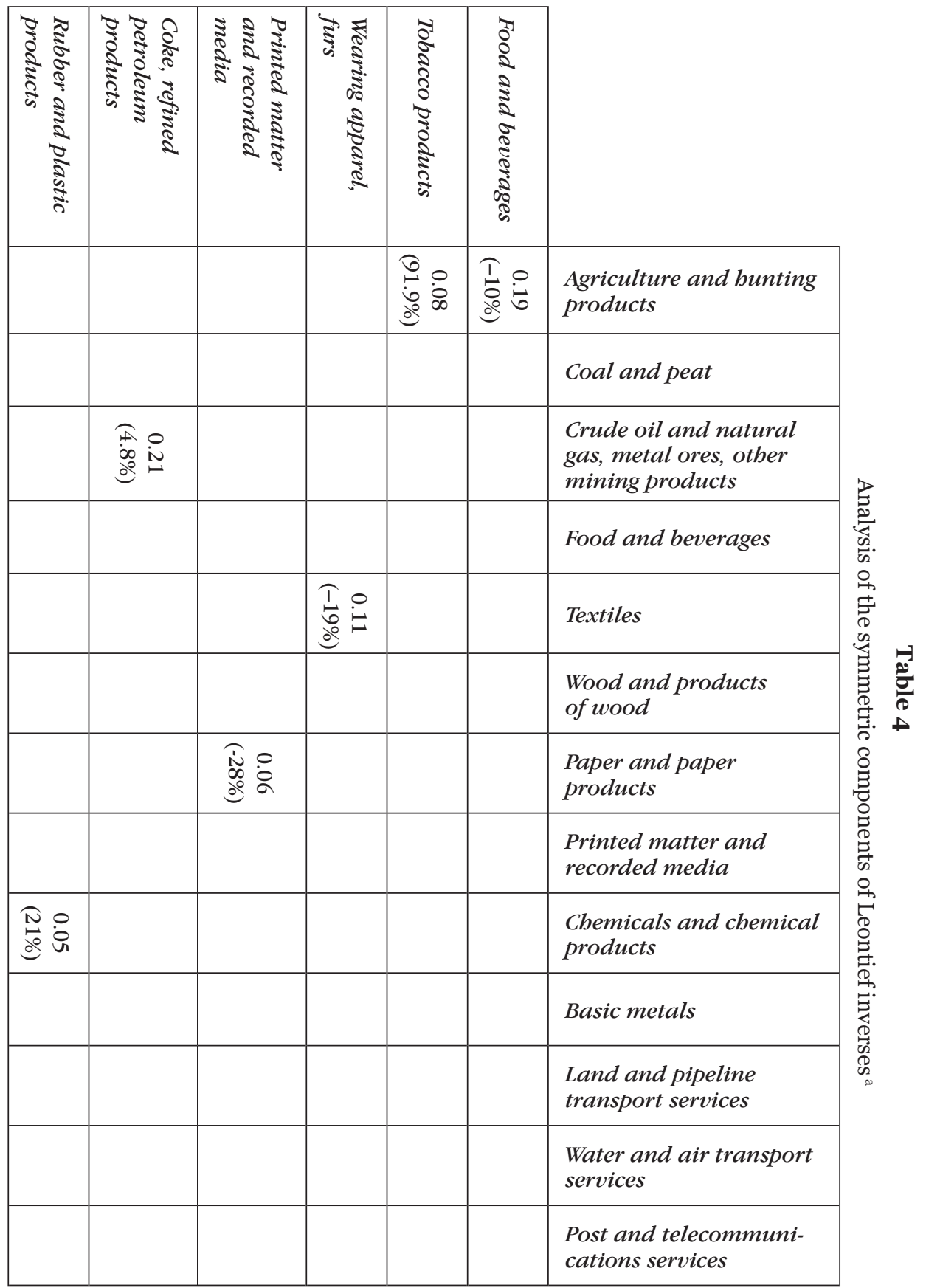

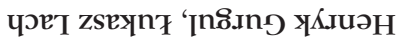


Table 4 cont

\begin{tabular}{|c|c|c|c|c|c|c|c|c|}
\hline Metal products & & & & & $\begin{array}{c}0.08 \\
(13 \%)\end{array}$ & & & \\
\hline $\begin{array}{l}\text { Furniture, other } \\
\text { manufactured } \\
\text { goods }\end{array}$ & & & $\begin{array}{c}0.04 \\
(-22 \%)\end{array}$ & & & & & \\
\hline $\begin{array}{l}\text { Recovered } \\
\text { secondary raw } \\
\text { materials }\end{array}$ & & & & & $\begin{array}{l}0.17 \\
(6 \%)\end{array}$ & & & \\
\hline $\begin{array}{l}\text { Electricity, gas, } \\
\text { steam and hot } \\
\text { water }\end{array}$ & $\begin{array}{c}0.08 \\
(28 \%)\end{array}$ & & & & & & & \\
\hline $\begin{array}{l}\text { Hotel and } \\
\text { restaurant services }\end{array}$ & & $\begin{array}{c}0.08 \\
(13 \%)\end{array}$ & & & & & & \\
\hline $\begin{array}{l}\text { Supporting transport } \\
\text { services; } \\
\text { tourism services }\end{array}$ & & & & & & $\begin{array}{c}0.06 \\
(67 \%)\end{array}$ & $\begin{array}{c}0.07 \\
(54 \%)\end{array}$ & \\
\hline $\begin{array}{l}\text { Other business } \\
\text { services }\end{array}$ & & & & $\begin{array}{c}0.04 \\
(29 \%)\end{array}$ & & & & $\begin{array}{l}0.06 \\
(93 \%)\end{array}$ \\
\hline
\end{tabular}

a In the brackets, we present the corresponding percentage change of the coefficient of symmetric components of Leontief inverses in 2005 with respect to the value in 2000 . 


\begin{tabular}{|c|c|c|c|c|c|}
\hline 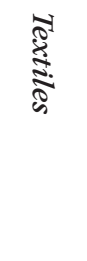 & 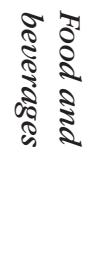 & 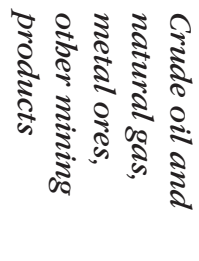 & $\begin{array}{l}5 \\
5 \\
0 \\
5 \\
5 \\
5 \\
5 \\
5 \\
5\end{array}$ & 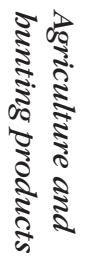 & \\
\hline & & & & 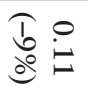 & Food and beverages \\
\hline & & & & $\begin{array}{l}\text { 怠 } \\
\text { @o }\end{array}$ & Tobacco products \\
\hline $\begin{array}{ll}\infty & 0 \\
\dot{0} & \dot{1} \\
\dot{0} & i\end{array}$ & & & & & Wearing apparel, furs \\
\hline & & & & & $\begin{array}{l}\text { Printed matter and } \\
\text { recorded media }\end{array}$ \\
\hline & & $\begin{array}{l}\text { I } 0 \\
\text { î } \\
\text { de }\end{array}$ & & & $\begin{array}{l}\text { Coke, refined petroleum } \\
\text { products }\end{array}$ \\
\hline & & & & & $\begin{array}{l}\text { Rubber and plastic } \\
\text { products }\end{array}$ \\
\hline & & & & & Metal products \\
\hline & & & & & $\begin{array}{l}\text { Furniture, other } \\
\text { manufactured goods }\end{array}$ \\
\hline & & & & & $\begin{array}{l}\text { Recovered secondary } \\
\text { raw materials }\end{array}$ \\
\hline & & & 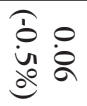 & & $\begin{array}{l}\text { Electricity, gas, steam } \\
\text { and bot water }\end{array}$ \\
\hline & $\begin{array}{l}\hat{P} \\
\text { i } \\
\text { do }\end{array}$ & & & & $\begin{array}{l}\text { Hotel and restaurant } \\
\text { services }\end{array}$ \\
\hline & & & & & $\begin{array}{l}\text { Supporting transport } \\
\text { services; tourism services }\end{array}$ \\
\hline & & & & & Real estate services \\
\hline & & & & & Other business services \\
\hline
\end{tabular}


Table 5 cont

\begin{tabular}{|c|c|c|c|c|c|c|c|c|}
\hline $\begin{array}{l}\text { Wood and } \\
\text { products of wood }\end{array}$ & & & & $\begin{array}{c}0.06 \\
(-18 \%)\end{array} \mid$ & & & & \\
\hline $\begin{array}{l}\text { Paper and paper } \\
\text { products }\end{array}$ & $\begin{array}{c}0.09 \\
(-11 \%)\end{array}$ & & & & & & & \\
\hline $\begin{array}{l}\text { Chemicals and } \\
\text { chemical products }\end{array}$ & & $\begin{array}{c}0.07 \\
(15 \%)\end{array}$ & & & & & & \\
\hline Basic metals & & & $\begin{array}{c}0.09 \\
(12 \%)\end{array}$ & & $\begin{array}{c}0.18 \\
(0.9 \%)\end{array}$ & & & \\
\hline $\begin{array}{l}\text { Electricity, gas, } \\
\text { steam and hot } \\
\text { water }\end{array}$ & & & & & & & $\begin{array}{c}0.06 \\
(-0.1 \%)\end{array}$ & \\
\hline $\begin{array}{l}\text { Land and pipeline } \\
\text { transport services }\end{array}$ & & & & & & $\begin{array}{c}0.08 \\
(13 \%)\end{array}$ & & \\
\hline $\begin{array}{l}\text { Water and air } \\
\text { transport services }\end{array}$ & & & & & & $\begin{array}{c}-0.07 \\
(-33 \%)\end{array}$ & & \\
\hline $\begin{array}{l}\text { Post and telecom- } \\
\text { munications } \\
\text { services }\end{array}$ & & & & & & & & $\begin{array}{l}-0.07 \\
(32 \%)\end{array}$ \\
\hline
\end{tabular}

a In the brackets we present the corresponding percentage change of the coefficient of symmetric components of Leontief inverses in 2005 with respect to the value in 2000 . 
The largest balances occur in the pair of sectors Coke, refined petroleum products and Crude oil and natural gas, metal ores, otber mining products, the pair Food and beverages and Agriculture and bunting products, and the pair Recovered secondary raw materials and Basic metals. Analogous to the previous case, Table 5 presents the 15 largest (in terms of absolute value) upper triangu$\operatorname{lar}^{23}$ coefficients of matrix $\mathrm{Sa}^{*}$ with the corresponding elements of the matrix $\Delta \mathrm{Sa}^{*}$ (also in parentheses).

As one can see, the largest absolute value of averaged bilateral imbalance was found in the case of the pair of sectors Crude oil and natural gas, metal ores, other mining products and Coke, refined petroleum products. Although, it is difficult to relate these results with the hypotheses formulated in Section $3^{24}$.

To sum it all up, the results presented in this section allow us to formulate the list of sectors that, more or less, have preserved the status of the key sectors in Poland. In turn, some sectors (especially the financial-intermediation- and foodand-agriculture-related ones), have significantly derailed, while services-related sectors (including transport, tourism, and trade services) have clearly gained in importance.

\section{Concluding remarks}

To the best of our knowledge, this paper fills the gap in the existing literature by examining key sectors in Poland over the transition period. The research was based on maximum entropy decomposition of the Leontief inverse applied to the highly-disaggregated input-output tables covering the period of 2000-2005.

\subsection{Key sectors}

The results prove that, during the period under study, one could formulate the group of sectors (especially food-and-agriculture-related ones) that, in general, have kept the status of key sectors in Poland. However, the importance of food-and-agriculture-related sectors in context of both forward as well as backward linkages declined. Also some manufacturing sectors, like the sectors

23 Analogously, matrices $\mathrm{Sa}^{*}$ and $\Delta \mathrm{Sa}^{*}$ are asymmetric with null diagonal.

24 These matrices help us to identify the pairs of sectors in the case of which the final demand-output relationship follows similar (matrix $\mathrm{S}^{*}$ ) or opposite patterns (matrix Sa*). Although these facts do not seem to provide a basis for a straightforward verification of the hypotheses listed in section 3, they provide some valuable information. For example, in the case of the pair of sectors of Agriculture and bunting products and Food and beverages, the symmetric relationship between final demand-output prevails, which implies that, most likely for this pair of sectors, both types of linkages either rise together or drop together. 
Key sectors after a decade of transition: Evidence from Poland

of Basic metals, Metal products, and Rubber and plastic products, were found as key sectors in both analyzed years. Also, the importance of chemical-related industrial sectors and the sector of Motor vebicles significantly increased in the period of 2000-2005. In other words, the results of this study suggest that not all industry branches in Poland experienced downturns in the second decade of the transition. These facts may suggest that Poland has largely managed to avoid the most-negative consequences of the process of de-industrialization that has been taking place in CEE from the beginning of the transition.

In the case of the services sectors, one could list a relatively long list of sectors that kept the status of key sectors (including tourism-, trade-, and transportrelated sectors). Some sectors (like the sector of Wholesale and commission trade services) have even changed the status from the forward-linkage-oriented (2000) to the key sector (2005).

\subsection{Sectorial classification after EU accession}

When discussing the results of this study, one should take a look at the history of the quarter century of transition in Poland. In the period of transition (especially after EU accession), some sectors of the Polish economy expanded. The empirical results suggest that the inflow of EU structural funds has had a significant impact on the development of the sector of construction, especially in the sphere of modernization of public infrastructure.

In this context, one should underline that, after the collapse of centrallyplanned economies, most of CEE countries (including Poland) started to reorganize their financial markets and opened themselves up to foreign capital. These circumstances, as mentioned in Section 3, caused the development of financial sector and led to the permanent rise of its importance. However, the results of our study suggest that, after the first decade of transition, one could observe a slowdown or even reversal of this trend. The financial-intermediation-related sectors, although some of which still being classified as key sectors in 2000, experienced significant decreases of almost all examined measures of importance (moreover, the sector of Insurance services was classified as weak-oriented sectors in both 2000 and 2005). Thus, one may claim that the scarcity of financial-sector-related services observed right after the collapse of centrally-planned economy in Poland was seriously reduced during the first decade of the transition and, as a consequence, development of this type of services decelerated in the second decade of transition.

After the fall of the Iron Curtain, Poles could travel abroad without any restrictions. At the same time, the tourist offer of the country has been continuously 
expanding. This, as a consequence, led to the rise in importance of travel-andtourism-related sectors confirmed by the formal analysis conducted in our study.

\subsection{Sectors losing importance}

The results prove that the heavy-industry-related sectors have, in general, lost in importance (in some cases, even changed status to only weak-oriented ones). At this place, it seems important to underline that, besides economic growth and increase of welfare of households, the process of transition and globalization has also implied some new challenges and risks. It is not obvious whether a transition economy would significantly benefit from rapid globalization, since integration with global markets leads to increased competition. The latter seems especially important in the case of Poland, which is still acquiring experience when it comes to dealing with various aspects of globalization and international competition on free markets (similar to other CEE transition economies). Thus, it is not surprising that from the beginning of 90s, one could observe the process of de-industrialization in Poland caused by the fact that many former state-owned large companies (especially those active in traditional branches, like mining or textiles) turned out to be uncompetitive with foreign companies (from Western Europe, but also the Far East). In addition, many new manufacturing companies founded on the basis of the assets of the insolvent state-owned firms (usually small and underinvested) also did not manage to face the requirements of free market competition.

Despite the work undertaken in this study, it is likely that some aspects of key sector analysis in Poland went undiscovered. Further research, however, requires the availability of new and reliable IO tables, Nevertheless, key sector analysis of the Polish economy seems both an interesting and important research topic, as in the last 25 years, this country has become an important EU-member from the CEE region, both in political and economic aspects.

\section{References}

[1] Białas, S. and Gurgul, H. (1998) 'Hypothesis About the Second Eigenvalue of the Leontief Matrix', Economic Systems Research-Journal of International Input-Output Association, vol. 10, pp. 285-289.

[2] Chenery, H.B. and Watanabe, T. (1958) 'International comparisons of the structure of production', Econometrica, vol. 26(4), pp. 487-521.

[3] Ćmiel, A. and Gurgul, H. (1996a) 'Dynamic input-output models with stochastic time lags', International Journal of Systems Science, vol. 27, pp. 857-861. 
Key sectors after a decade of transition: Evidence from Poland

[4] Ćmiel, A. and Gurgul, H. (1996b) 'Dynamic Input-Output Models with Stochastic Matrices and Time Lags', Economic Systems Research-Journal of International Input-Output Association, vol. 8, pp. 133-143.

[5] Ćmiel, A. and Gurgul, H. (1997), 'Stochastic Backward-Lag-Type Leontief Model', The Central European Journal for Operations Research and Economics, vol. 5, pp. 34-45.

[6] Ćmiel, A. and Gurgul, H. (2002) 'Application of maximum entropy principle in key sector analysis', Systems Analysis, Modelling, Simulation: A journal of mathematical modelling and simulation in systems analysis, vol. 42(9), pp. 1361-1376.

[7] Defourny, J. and Thorbecke, E. (1984) 'Structural path analysis and multiplier decomposition within a social accounting framework', Economic Journal, vol. 94, pp. 111-136.

[8] Gurgul, H. and Lach, L. (2013) 'Financial Development and Economic Growth in Poland in Transition: Causality Analysis', Czech Journal of Economics and Finance, vol. 62 (4), pp. 347-367.

[9] Gurgul, H. and Lach, Ł. (2014) 'Globalization and economic growth: Evidence from two decades of transition in CEE', Economic Modelling, vol. 36, pp. 99-107.

[10] Hewings, G.J.D. (1982) 'The empirical identification of key-sectors in an economy: a regional perspective', The Developing Economies, vol. 20, pp. $173-195$.

[11] Hewings, G.J.D. and Romanos, M.C. (1981) 'Simulating less developed regional economies under conditions of limited information', Geographical Analysis, vol. 13(4), pp. 373-390.

[12] Kalvet, T. and Kattel, R. (2006) Creative Destruction Management: Meeting the Challenges of the Techno-economic Paradigm Shift, Tallinn: Praxis.

[13] Kullback, S. (1970) Information Theory and Statistics, New York: Oxford University Press.

[14] Lenain, P. (2000) 'Poland's successful transition', OECD Observer (220) [Online] Available: http://www.oecdobserver.org/news/archivestory.php/aid/ 212/Polands_successful_transition.html [12 May 2014].

[15] Rasmussen, P. (1956) Studies in Inter-Sectoral Relations, Copenhagen: Einar Harks.

[16] Sethna, J. (2006) Statistical Mechanics, New York: Oxford University Press.

[17] Shannon, C.E. and Weaver, W. (1964) The Mathematical Theory of Communications, Urbana IL: University of Illinois Press.

[18] Sherman, J. and Morrison, W.J. (1950) 'Adjustment of an inverse matrix corresponding to a change in one element of a given matrix', Annals of Mathematical Statistics, vol. 21, pp. 124-127. 
[19] Sonis, M. and Hewings, G.J.D. (1992) 'Coefficients change in input-output model: theory and applications', Economic Systems Research, vol. 4, pp. 143-157.

[20] Sonis, M. and Hewings, G.J.D. (1989) 'Errors and sensitivity in input-output analysis: new approach', in Miller, R., Polenske, K. and Rose, A. (eds), Frontiers in Input-Output Analysis, New York: Oxford University Press.

[21] Theil, H. (1967) Economics and Information Theory, New York: Elsevier.

\section{Appendix}

Below, we will demonstrate that MPM has the property of maximum entropy (Shannon and Weaver 1964, Theil 1967, Kullback 1970). Assume that matrix $\mathrm{Q}=\left[Q_{i j}\right]$ consists of positive elements and define:

$$
\sum_{j} Q_{i j}=B_{i \bullet}, \sum_{i} Q_{i j}=B_{\bullet j} \text { and } \sum_{i j} Q_{i j}=V
$$

Let $\left(X, F, P_{i}\right)$ for $i=1,2$ be the probability spaces, each of which consist of a basic set of elements $x \in X$ and a collection $F$ of all possible events (sets) constructed on the basis of elements of the sample space $X$ for which probability measures $P_{i},(i=1,2)$ have been defined. From the assumption that the probability measures $P_{1}$ and $P_{2}$ are absolutely continuous with respect to one another, it follows that there exists a probability measure $\mu^{25}$ and functions $f_{i}(x), i=1,2$ called the generalized probability densities (Radon-Nikodym derivatives), which:

- are unique up to sets of $\mu$-zero probability,

- are measurable with respect to $\mu$,

- fulfil the condition $0<f_{i}(x)<\infty$ almost everywhere with respect to $\mu$,

- for all $A \in F$ fulfil the condition $P_{i}(A)=\int_{A} f_{i}(x) d \mu(x), i=1,2$.

After taking the Taylor expansion $\log x=x-1-\frac{1}{2 c^{2}}(x-1)^{2}, c \in(\min \{1, x\}$,
$\{1, x\})$ one gets: $\max \{1, x\}$ ) one gets:

$$
\begin{gathered}
\int_{X} f_{1}(x) \log \frac{f_{2}(x)}{f_{1}(x)} d \mu(x)=\int_{X} f_{1}(x)\left\{\frac{f_{2}(x)}{f_{1}(x)}-1-\frac{1}{2 c^{2}}\left(\frac{f_{2}(x)}{f_{1}(x)}-1\right)^{2}\right\} d \mu(x)= \\
=\int_{X}\left(f_{2}(x)-f_{1}(x)\right) d \mu(x)-\frac{1}{2 c^{2}} \int_{X} f_{1}(x)\left(\frac{f_{2}(x)}{f_{1}(x)}-1\right)^{2} d \mu(x)=
\end{gathered}
$$

${ }^{25}$ For example, $\mu=\frac{1}{2}\left(P_{1}+P_{2}\right)$. 


$$
\begin{gathered}
=\int_{X} f_{2}(x) d \mu(x)-\int_{X} f_{1}(x) d \mu(x)-\frac{1}{2 c^{2}} \int_{X} f_{1}(x)\left(\frac{f_{2}(x)}{f_{1}(x)}-1\right)^{2} d \mu(x)= \\
=1-1-\frac{1}{2 c^{2}} \int_{X} f_{1}(x)\left(\frac{f_{2}(x)}{f_{1}(x)}-1\right)^{2} d \mu(x) \leq 0
\end{gathered}
$$

The inequality $\int_{X} f_{1}(x) \log \frac{f_{2}(x)}{f_{1}(x)} d \mu(x) \leq 0$ is known as the basic inequality in information theory. Using this inequality to the case of two-dimensional distributions with the density function $f_{X Y}(x, y)$ and the product of one-dimensional distributions $f_{X}(x) f_{Y}(y)$ we obtain:

$$
\int_{X} f_{X Y}(x, y) \log \frac{f_{X}(x) f_{Y}(y)}{f_{X Y}(x, y)} d \mu(x, y) \leq 0
$$

and then:

$$
\begin{gathered}
-\int_{X} f_{X Y}(x, y) \log f_{X Y}(x, y) d \mu(x, y) \\
\leq-\int_{X} f_{X}(x) \log f_{X}(x) d \mu(x)-\int_{X} f_{Y}(y) \log f_{Y}(y) d \mu(y)
\end{gathered}
$$

The above inequality can be rewritten in the following form:

$$
H(X, Y) \leq H(X) H(Y)
$$

where:

$$
H(X)=-\int_{X} f_{X}(x) \log f_{X}(x) d \mu(x)
$$

is called the entropy of random variable $X$ (or its distribution).

Analogically:

$$
H(X, Y)=-\int_{X} f_{X Y}(x, y) \log f_{X Y}(x, y) d \mu(x, y)
$$

is called the entropy of two-dimensional random variable $(X, Y)$ (or its distribution).

In particular, in the case of a discrete two-dimensional distribution, the above formula takes the form of the inequality $\sum_{i, j} p_{i, j} \log \frac{p_{i \bullet} p_{p_{j}}}{p_{i j}} \leq 0$. Hence:

$$
-\sum_{i, j} p_{i, j} \log p_{i j} \leq-\sum_{i} p_{i \bullet} \log p_{i \bullet}-\sum_{j} p_{\bullet j} \log p_{\bullet} j
$$


If one applies this inequality to the probabilistic distribution defined by matrix $\mathbf{Q}$ (i.e. a distribution for which $p_{i j}=\frac{Q_{i j}}{V}$ and the product $\mathbf{M}$ of the marginals is given by $p_{i \bullet}=\frac{B_{i \bullet}}{V}$ and $p_{\bullet j}=\frac{B_{\bullet j}}{V}$ ) and takes into account the definition of entropy given in (A.6):

$$
H(\mathbf{Q})=-\sum_{i, j} p(i, j) \ln p(i, j)=-\sum_{i, j} \frac{Q_{i, j}}{V} \ln \frac{Q_{i, j}}{V}
$$

it is straightforward to prove:

$$
\begin{gathered}
H(\mathbf{Q})=-\sum_{i, j} \frac{Q_{i j}}{V} \ln \frac{Q_{i j}}{V} \leq-\sum_{i, j} \frac{B_{i \bullet} B_{\bullet}}{V^{2}}\left(\ln \frac{B_{i \bullet}}{V}+\ln \frac{B_{\bullet} j}{V}\right)= \\
=-\sum_{i, j} \frac{B_{i \bullet} B_{\bullet} j}{V^{2}} \ln \frac{B_{i \bullet} B_{\bullet}}{V^{2}}=H(\mathbf{M}) .
\end{gathered}
$$

Inequality (A.10) proves that MPM has the property of maximal entropy in the class of all matrices with fixed marginals. For the case where there are simultaneous changes in two places $\left(i_{0}, j_{0}\right)$ and $\left(i_{1}, j_{1}\right)$ in a direct inputs matrix, a particular formula analogous to (14) can be established (Hewings and Romanos, 1981). 